This author's manuscript has been accepted for publication by the Journal of British Studies and will appear subject to copyediting and remains the copyright of Cambridge University Press. 


\title{
J. A. Hobson and the Machinery Question
}

\author{
Daniel C.S. Wilson*
}

\begin{abstract}
The effects of industrialization on British life were the subject of a broad and intelligible set of debates during the early nineteenth century, often described as the "machinery question." This question, concerning what today is called "technology," was framed to include its effects on the whole of human life — an approach rarely seen by the late century; a period marked instead by disciplinary specialization. An exception to this trend can be found in the work of the heterodox economic and social critic J.A. Hobson (1858-1940)—better known for his critique of imperialism. From the 1890s, Hobson reopened the machinery question by offering an ethical analysis of mechanization which was both holistic and long-standing. In addition to proposing this new lens for viewing Hobson, this article explores the challenges - as well as the opportunities - facing those returning to the machinery question more generally.
\end{abstract}

* Daniel C.S. Wilson is a research fellow at CRASSH, University of Cambridge. He is grateful to archival staff at Conway Hall, the LSE, and the Hull History Centre, as well as to Jos Betts, Rowan Boyson, Gregory Claeys, Thomas Dixon, Stuart Jones, Michael LedgerLomas, Peter Mandler, Niall O'Flaherty, and Frank Trentmann for comments on earlier versions of this paper. The research for this article was supported at different times by the AHRC and the Leverhulme Trust. 


\section{J. A. Hobson and the Machinery Question}

Machinery has long been recognized as an important factor in the modern history of Britain — both at the academic level, where it has perhaps been taken for granted (and so underexamined) and also in popular culture, where its mythologies retain the power to stoke controversy. A recent example can be found in the heated responses to the opening ceremony of the 2012 London Olympics, in which a historical tableau including sublime machines, factories, and forges featured alongside the grubby Victorian mechanics who worked them. The choice of such a depiction of the first industrial nation was heralded by some commentators as an honest and demythologized image of British achievement, while others derided the choice of this dark and satanic theme at such an occasion as "socialist." The place of machinery in British culture and a fortiori in its histories is thus marked by contention as well as by an awkward ambivalence which is not so much unresolved as undigested, in part because the question has rarely been subject to sustained critical attention. $^{2}$

By contrast, during the second quarter of the nineteenth century, in the immediate aftermath of the Industrial Revolution, the "machinery question" was debated in highly visible settings at the heart of public and intellectual life in Britain. The prospect — if not yet the full reality_of new machinery prompted debate among political economists, social

\footnotetext{
${ }^{1}$ For a sense of the local responses as well as an anthropological perspective, see Hélène Mulholland, "Opening ceremony was a Trojan horse for socialist values," The Guardian, 29 July 2012; James Kirkup, "Olympics opening ceremony was 'honouring socialism' says shock jock Rush Limbaugh," The Daily Telegraph, 31 July 2012; Lauren Collins, "Danny Boyle Wins the Gold," The New Yorker, 27 July 2012.

${ }^{2}$ Among the few mainstream commentators to have devoted energy to the issue are iconoclastic figures such as Raymond Williams and Humphrey Jennings; see, for example, their respective works, Culture \& Society, 1780-1950 (London, 1958) and Pandaemonium, 1660-1886: The Coming of the Machine, as seen by contemporary observers (London, 1987). There continues to be a lively debate between economic historians over the causes - as well as the existence - of the Industrial Revolution, but there is even less engagement with these questions among non-specialists today than there was during the twentieth century.
} 
critics, workers, and industrialists as part of a broadly continuous discourse. Indeed it was in the crucible of the machinery question that the very discipline of political economy was forged: as Maxine Berg puts it, "The period of intense debate on the machinery issue coincided with the making of this new discipline [...] a unique object of inquiry and a specific intellectual framework of analysis were established [...] and it was one of the first concerns of economic analysis to provide an adequate theoretical explanation." However, these early-Victorian debates prompted a wider range of questions about machinery than those posed by the political economists. As Berg puts it, "Would it bring wealth only to those who owned it, or to society as a whole? Would it make work or create unemployment? Would it unite society or foment class conflict?"3 Opinions about the likely effects of machinery on wages, productivity, skill, and workloads were diverse: Tories and laborers often shared their skepticism — for different reasons - in the face of a bullish industrial bourgeoisie, while even the "middle-class science" of political economy produced only uncertainty, because the same theories which first championed the machine could also be turned against it by critics. The interlocking nature of political and economic issues during that period made it difficult to avoid taking a position on mechanization. The machinery question therefore underscored socio-political debate in myriad ways that were both implicit and explicit. If the impact of this debate-which might broadly be construed as ethical-on the political and industrial affairs of the period is difficult to gauge, it is because the substantive questions about the merits of mechanization remained unresolved. But even though the machinery question was not settled one way or the other, the progress of machinery through

\footnotetext{
${ }^{3}$ Maxine Berg, The Machinery Question and the Making of Political Economy, 1815-1848 (Cambridge, 1980) 2-3.
} 
the economy continued regardless and so, in a practical sense, the history of the longer Victorian period shows that it was answered in the affirmative with absolute decisiveness. ${ }^{4}$

Subsequent events make it difficult to reconstruct the perspective of 1848 , from which the inevitability of technical progress might still be questioned. Such ongoing discussion as there has been is usually seen as bifurcating from that point onwards into two divergent channels: on the one hand, into a professionalizing discourse of political economy and economics, most often concerned with the efficient employment of capital; and on the other, into a more aesthetic discourse of social criticism rooted in some degree of anti-industrialism. On such a view, the latter strand included Romantic voices such as William Morris and John Ruskin, while the former included hard theorists like Stanley Jevons and Alfred Marshall. ${ }^{5}$ However, such a dualistic account of industrial discourse risks occluding a body of thought located somewhere in the middle. Sometimes self-consciously, a range of late nineteenthcentury thinkers_-including Arnold Toynbee and J. A. Hobson—attempted to straddle this gap by re-posing a holistic version of the earlier machinery question. Echoing the way that those early debates had been joined concurrently by figures as diverse as Coleridge, Ricardo, and Bentham, these late-century thinkers admitted a diversity of material in their inquirieseconomic, sociological, and cultural—which transcended any single disciplinary specialism.

Attempts to theorize machinery in the late nineteenth century were holistic because the impossibly multifarious nature of the subject demanded it. The attempts to analyze the profound impact of machinery took place against a backdrop of rapid academic specialization and fragmentation and can thus be seen as a protean (and short-lived) form of

\footnotetext{
${ }^{4}$ Examples of the rhetoric of "inevitable" technical progress hardly need enumerating while, conversely, it is difficult to produce a single example of any society since the nineteenth century deciding democratically or otherwise to forego a new technique of any sort.

${ }^{5}$ Notwithstanding J.S. Mill's aspiration to unite these two impulses in a reformed political economy this "schism," identified by Donald Winch as a stereotype, persists in textbook accounts of British culture and is entrenched by the seemingly impermeable disciplinary wall between cultural histories on the one hand and histories of economics on the other. For the exception that proves the rule see Winch, Riches and Poverty: an Intellectual History of Political Economy in Britain, 1750-1834 (Cambridge, 1996) 6 \& 416-22.
} 
interdisciplinary research. Nonetheless, such efforts usually involved some form of historical inquiry_for example in Arnold Toynbee's "Lectures on the Industrial Revolution” (1884), which first deployed the term "Industrial Revolution" in English—and formed a tradition which would culminate in the work of J.A. Hobson. ${ }^{6}$ A key feature of Hobson's work was the way in which — almost uniquely among social and political thought of the late nineteenth century - it engaged with the question of machinery as if it remained an open question. This stance was made possible by a historical inquiry that revealed the contingency of the present: that things could have been and — especially for Hobson — might still be otherwise.

Whereas historians have long recognized and interrogated the polyvalent, yet highly formative, role of technology in US culture there has been no comparable framework of analysis for Britain. In the US context, machinery has been seen - in the broadest sense - to have produced the nation and, as such, scholars have considered the ways in which it has been understood by Americans in turn as an incongruous presence "in the garden," as part of a "second creation," or even as a "religion."7 The scarcity of such perspectives on the British case may perhaps be explained historically by the peculiarities of nineteenth-century British socialism and the lag in the reception of Karl Marx's Capital (whose long chapter on machinery had an imperceptible impact on contemporary British thinkers); or, perhaps the emphasis on aesthetics and landscape (rather than the factory floor) as historiographical sites of disputation has created a restricted lens through which to survey the contours of the machinery question in its ongoing British forms. ${ }^{8}$ A further reason for what Berg describes as

\footnotetext{
${ }^{6}$ Notwithstanding the earlier Franco-German origins of the concept of an Industrial Revolution. ${ }^{7}$ Leo Marx, The Machine in the Garden: Technology and the Pastoral Ideal in America (New York, 1964); David Nye, America As Second Creation: Technology and Narratives of New Beginnings (Cambridge, MA, 2003); David Noble, The Religion of Technology (New York, 1997). The tradition can be traced back at least as far as Thorstein Veblen who arguably coined the term "technology" in its current form around 1900 (and who was also a correspondent of Hobson's). See Erik Schatzberg, "Technik Comes to America," Technology and Culture 47, no. 3 (2006): 486-512.

${ }^{8}$ While clearly not to blame for this trend, works such as Harriet Ritvo, The Dawn of Green: Manchester, Thirlmere, and Modern Environmentalism (Chicago, 2009) indicate the framework within which the impact of industry has tended to be situated in modern British studies. Scholars
} 
the "remarkable indifference" of historians to the machinery question may lie, as she suggests, "in the previous splintering of many fields of history — the history of economic thought, the history of science and social science, the history of social and economic policy, economic history, and political and social history"-a splintering which has militated against the historical analysis of machinery, and which suggests a parallel problem for attempts to theorize "technology" more generally.

This article will address these issues by recovering the attempts of one prominent intellectual to digest and to tackle the machinery question as it was from the 1890s. A public moralist, economist and social theorist, John Atkinson Hobson (1858-1940) was one of the most eclectic intellectuals at work in late nineteenth- and early twentieth-century Britain. With a fitting neologism, the taxonomist Patrick Geddes once described Hobson's main concern as the creation of "etho-economics." "Although Hobson is best known for his critical theory of imperialism, as well as for his practical contributions to the British center-Left, it was his attempt to bind ethics to economics which provided the overarching framework of his thought and which has tended to shape its reassessment. In the 1890s, parliamentary Liberalism came under pressure not only due to the combustible question of Ireland, but also due to the external threat building on its left flank from the radicals and reformers of the labor movement. A key figure among the group who sought to remake the fractured Liberal tradition - the New Liberals — Hobson envisaged a unified science of ethics, drawing on different intellectual disciplines as the basis for reform. Although it remained an open question as to what exactly this would entail, Hobson was certain that to address the manifold social problems of his time would require a new approach. Whereas middle-class Victorian

tracing Victorian literary responses to machinery, on the other hand, have understandably focused on a particular canon, beginning with Carlyle and Dickens, rather than the more programmatic responses to be found in social thought. See Herbert L. Sussman, Victorians and the Machine: The Literary Response to Technology (Cambridge, MA, 1968) and most recently Tamara Ketabgian, The Lives of Machines: The Industrial Imaginary in Victorian Literature and Culture (Ann Arbor, 2011).

${ }^{9}$ Patrick Geddes, "Review of Hobson's Freethought in the Social Sciences", Sociological Review 18, no. 3 (1926): 256-57. 
philanthropy had been rooted in feelings of sympathy or charity, the new material conditions at the end of the nineteenth century demanded a systematic view of capitalism that might produce holistic solutions to some of its problems. This article focuses on a theme not previously recognized in Hobson's thought in order to sketch how these broader concerns took their concrete form. Revisiting his writings in the years on either side of 1900 reveals Hobson's consistent interest in the question of machinery: an etho-economic question of the first order and one which would be central to any attempt at social and political reform.

This article proposes the idea of the machine as a new framework for considering Hobson's thought, which in turn highlights the way machinery and by extension "technology" has been treated in modern British thought more broadly. The example of Hobson is particularly instructive in relation to a key issue to emerge in the following discussion: his position outside of traditional intellectual structures points to the general problem of disciplinarity in the analysis of machinery which, since the late nineteenth century, has never found an obvious single locus for its prosecution. In the course of considering Hobson and the machine question, this article will elucidate the nature of his socalled etho-economics and show why the question of machinery was a topic that demanded a unitary vision of a moral and political economy. The article begins by examining the background to Hobson's major work to investigate machinery with a special focus on his sources. The central sections concern the principal arena in which the effects of machinery were felt; namely, that of the workplace, before moving to a consideration of the broader intellectual scene, including the thought of John Ruskin. The article concludes with a reflection on what the problem of machinery can tell us about Hobson in particular and historical studies in general. 


\section{HOBSON, MACHINES, AND HISTORY}

There remains no definitive biography of Hobson and since his own memoir was restricted to his intellectual formation, for such an eclectic and popular writer, there is a relative dearth of detail or anecdote. Before considering his work on machinery, therefore, it is first necessary to situate him in relation to the historiography of the period. The status of Hobson's economic thought remains as disputed today as it was during his lifetime and so serves as a useful marker of the contested nature of that field. Hobson was frequently dismissed by neoclassical contemporaries such as Alfred Marshall as a dilettante who did not understand the subject sufficiently. However, to restrict an assessment to the orthodox voices such as Marshall's (which have in retrospect formed a master discourse in economics) would not fully represent his reception by contemporaries. To a broader range of critics, including H.N. Brailsford, Hobson was "the most original and persuasive thinker of his day on economic questions." "10 The Ratcliffes' suggestion that "An epoch in economic thought was made when, with his friend Mummery, he published (1889), The Physiology of Industry," appears less eccentric in light of John Maynard Keynes's agreement that the book was the first of "many volumes in which for nearly fifty years Mr Hobson has flung himself with unflagging, but almost unavailing, ardour and courage against the ranks of orthodoxy." "11 Of Hobson's many other interlocutors the most significant was Lenin who, despite dismissing him as a bourgeois reformer, made use of Hobson's celebrated critique of imperialism in his own

\footnotetext{
${ }^{10}$ H. N. Brailsford, The Life Work of J. A. Hobson (Oxford, 1948), 3.

${ }^{11}$ John Maynard Keynes, The General Theory of Employment, Interest and Money (Basingstoke, 2007), 364-65; S. K. Ratcliffe and K. M. Ratcliffe, "J. A. Hobson, 1858-1940", Monthly Record 63, no. 7 (1958): 6-7; A. F. Mummery and J. A. Hobson, The Physiology of Industry: Being an Exposure of Certain Fallacies in Existing Theories of Economics (London, 1889).
} 
work. ${ }^{12}$ This ambivalent reception continues to the present and is marked by the recent appearance of entries on Hobson in both orthodox and radical dictionaries of economics. ${ }^{13}$

Hobson was, of course, aware that his work divided opinion and offered a succinct account of the reasons. In his autobiographical Confessions of an Economic Heretic, written shortly before his death, Hobson explained that the two "heresies" he was seen to have committed ran to the heart of both orthodox economics and Victorian morality. ${ }^{14}$ Hobson questioned the basis of the classical economic theories that prescribed laissez-faire and also the principle that thrift and saving were incontrovertibly good. The latter formed part of Hobson's belief in the possibility of underconsumption, a theory that stressed the dangers of oversaving (especially by the idle rich) as part of a demand-side account of economic depression. Although not the first to hold these views, Hobson was ostracized by academic economists and prevented from lecturing in the University of London. ${ }^{15}$ In these heresies, according to one commentator, can be "found the explanation of the singular fact that $\mathrm{Mr}$. Hobson has never occupied any position as a teaching economist in this country." ${ }^{\text {Hobson }}$ made a virtue out of necessity and, instead, forged an independent career writing and lecturing, free from what he considered the dogma of academic economics. ${ }^{17}$

\footnotetext{
${ }^{12}$ Preface to the French edition, V. I. Lenin, L'impérialisme, dernière étape du capitalisme (Paris, 1923); J. A. Hobson, Imperialism: A Study (London, 1902).

${ }^{13}$ Two of several examples include, John Eatwell, Murray Milgate, and Peter Newman, ed., The New Palgrave: A Dictionary of Economics (London, 1987) and Philip Arestis and Malcolm C. Sawyer, ed., A Biographical Dictionary of Dissenting Economists (Cheltenham, 2000).

${ }^{14}$ J. A. Hobson, Confessions of an Economic Heretic: The Autobiography of J.A. Hobson, ed. Michael Freeden (Hassocks, 1976).

${ }^{15}$ The source of these machinations was most likely the economist, H. S. Foxwell. See Donald Winch, "A Composition of Successive Heresies': The Case of J. A. Hobson," in Wealth and Life: Essays on the Intellectual History of Political Economy in Britain, 1848-1914 (Cambridge, 2009) and also, Alon Kadish, "Hobson and the Extension Movement," in Reappraising J. A. Hobson: Humanism and Welfare, ed. Michael Freeden (London, 1990).

${ }^{16}$ G. D. H. Cole, "Review of Hobson's Confessions of an Economic Heretic", Political Quarterly 9, no. 3 (1938): 439-41.

${ }^{17}$ For Hobson's scathing views on academia, written during the year under discussion below, see J. A. Hobson, "The Academic Spirit in Education", Contemporary Review 63 (February 1893): 236-247.
} 
Despite this iconoclasm, Hobson's work can be seen as consonant with New

Liberalism: a strand of social-liberal thought that emerged in the late nineteenth century. ${ }^{18}$

Although recognizing Hobson's centrality to this milieu, both Stefan Collini and Peter Clarke accord Hobson less prominence than they do Graham Wallas, J.L. Hammond and L.T.

Hobhouse, while in a more recent landmark study of this period, John Burrow regrets that despite tugging at his conscience, Hobson needed to be excluded due to a lack of space. ${ }^{19}$ Michael Freeden has done most to rehabilitate Hobson by stressing his contributions to the canon of political thought. ${ }^{20}$ Nonetheless, Hobson's preoccupation with the machinery question has been consistently overlooked. A possible reason for this is that the question of machinery has rarely been acknowledged as a political one and so has not greatly interested historians of political thought. ${ }^{21}$ This trend within British intellectual history becomes especially visible with respect to Hobson and so represents a lacuna which this article seeks in part to address. Two of Hobson's first three books were The Physiology of Industry (1889) and The Evolution of Modern Capitalism: A Study of Machine Production (1894), and his interest in machinery continued over the following twenty years. Yet Freeden's 1978 book The New Liberalism — which does place Hobson in center stage - contains no mention of machines or technology. ${ }^{22}$ This reflects a great deal of the general histories written about

\footnotetext{
${ }^{18}$ Michael Freeden, The New Liberalism: An Ideology of Social Reform (Oxford, 1978); Stefan Collini, Liberalism and Sociology: L. T. Hobhouse and Political Argument in England, 1880-1914 (Cambridge, 1979); P. F. Clarke, Liberals and Social Democrats (Cambridge, 1978).

${ }^{19}$ John Burrow, The Crisis of Reason: European Thought, 1848-1914 (New Haven, CT, 2000), xiv.

${ }^{20}$ For an eloquent account of Hobson's anti-imperialism and "visionary" anticipation of British liberal-social politics, see Michael Freeden, "J. A. Hobson As a New Liberal Theorist: Some Aspects of His Social Thought Until 1914", Journal of the History of Ideas 34, no. 3 (1973): 421-43.

${ }^{21}$ Even today the question of technology is seldom construed in explicitly political terms outside of a group of critics working within the traditions of Science Studies or History and Philosophy of Science - a group of critics who form a minority even within these disciplines. For two examples, see the work of Langdon Winner or, reflexively, Dominique Pestre, "La Politique Des Science Studies," Nouvelle Revue des Livres 1 (2011): 58-61.

${ }^{22}$ The same applies to Peter Cain's 2002 study of Hobson which is the only work I have found to mention Hobson's 1893 article about machinery (discussed below), but which does so with respect to its arguments about underconsumption and trust formation, noting Hobson's interest in machinery, but not commenting on it. Peter Cain, Hobson and Imperialism: Radicalism, New Liberalism, and
} 
Britain's second industrial revolution and, strangely, a search of the indices of the four books discussed above reveals no reference to any of the terms "machine," "technology," "technical," "industry," or "mechanical." 23 Similarly, those landmark studies of the long finde-siècle which do engage with material conditions are colored by a form of presentism which skews their attention towards those artifacts which would in hindsight go on to shape the world of today. ${ }^{24}$ While it is clearly important to chart the arrival of the first automobiles and airplanes around the turn of the century, the year 1901 was more significant for being the historical high point of British industrial employment; with millions then at work in factories, their experiences are perhaps of greater contemporary significance than the relatively small number of automobiles on the roads. ${ }^{25}$

The history of technology has often had an awkward relation to broader questions in British history and so has remained strangely marginal. ${ }^{26}$ However, when understood in its fullest context as both knowledge and practice, theory and object, technology (and its history) can suggest modes of explanation which are otherwise inaccessible. For a small group of social investigators in late nineteenth-century Britain, and above all for Hobson, machinery

Finance, 1887-1938 (Oxford, 2002), 32-33. This is an otherwise exemplary account of Hobson's economic thought.

${ }^{23}$ While difficult to prove a negative, it is at least indicative that in addition to these monograph indices, a title search for "machine," "machinery," or "technology" in the combined total publication runs of Albion, English Historical Review, Journal of British Studies, and Victorian Studies only returns nine articles, of which fewer than half are actually about machinery in the Hobsonian sense. [Searched JSTOR on 8 April 2014]

${ }^{24}$ The conceptual organization of Stephen Kern's pioneering The Culture of Time and Space, 18801918 (Cambridge, MA: 2003; 1983) by categories of "Speed," "Time," etc., does not leave space for the more mundane considerations of industry or the workplace.

${ }^{25}$ Historical surveys thus tend towards what David Edgerton describes as "innovation-centrism" at the cost of a concern for the lived experience: "From Innovation to Use: Ten Eclectic Theses on the Historiography of Technology," History and Technology 16, no. 2 (1999), 111-36. On the scale of industrial occupation in 1901, see one survey which avoids such pitfalls: Jose Harris, Private Lives, Public Spirit: A Social History of Britain, 1870-1914 (Harmondsworth, 1994): 126. There were approximately five-thousand motor vehicles in Britain at the time of the 1903 Motor Car Act. ${ }^{26}$ The work of David Edgerton remains the honorable exception that proves this rule, and not only because of Edgerton's belief that the unexamined concept of "technology" obscures more than it illuminates. One of the few mainstream histories in recent years to have examined technological questions specifically during the period under discussion here is Bernhard Rieger, Technology and the Culture of Modernity in Britain and Germany, 1890-1945 (Cambridge, 2005). 
was the connective tissue that bound political economy to ethics, aesthetics, and politics. In order to make sense of Hobson's thought and its context we must, likewise, engage with what was clearly one of his major concerns. Despite the centrality of machinery to the history of economic thought, it has tended to be conceptualized too thinly to have been taken up by many historians as a concern in itself, with "technology" often serving as an unexamined code-word for an inevitable force of historical change, experienced in a uniform way. ${ }^{27}$ Indeed, the history of the concept of "technology" itself - this crucial twentieth-century keyword - has yet to be written, and so its use remains marked by habitual anachronism: the word "technology" did not exist in its current English form before around 1900 and yet historians deploy it routinely in a way long prohibited in comparable cases. ${ }^{28}$ It is sometimes the case that historians reproduce the trends they study. Just as nineteenth-century attempts to investigate the role of machinery were often conducted haltingly, in impoverished isolation from broader forms of social inquiry, so the question of technology has remained at the edges of the broad canvas of historical research, investigated more often as a specialist problem in a sub-field of the history of science, rather than as a part of social, political, or intellectual history.

This historiographical sequestration of technology is ironic since the historical mode has often been the starting point for those social investigators who have sought to discuss the

\footnotetext{
${ }^{27}$ Examples of this tendency are too numerous to mention but major historians who have, by contrast, addressed the uneven adoption and impact of machinery include Raphael Samuel, "Workshop of the World: Steam Power and Hand Technology in Mid-Victorian Britain." History Workshop Journal 3 (1977), 6-72 and Harris, Private Lives, Public Spirit, e.g., 138: "Craft resistance to production-line processes centred, nearly always, not upon machinery per se but upon the question of who should man and control it." This point applies a fortiori in the most infamous case of new machinery, namely, that of the Luddites, whose historical misrepresentation continues to this day (apart from in a handful of works - mainly in French, such as François Jarrige, Face Au Monstre Mécanique. Une Histoire Des Résistances À La Technique (Paris, 2009) - and following in the tradition started by Eric Hobsbawm, "The Machine Breakers," Past \& Present 1, no. 1 (1952): 57-70).

${ }^{28}$ Contrast this with the ban on the word "scientist" in any discussion of the era before c.1830. This foundational dictum of the history of science (i.e., that we must not speak of "scientists" but only of "natural philosophers") is not only a terminological injunction, but simultaneously contains a meaningful historical claim.
} 
effects of machinery. This was especially true in late nineteenth-century Britain, a society in the midst of rapid technological change, in which the first histories of industrialization were also beginning to be written. ${ }^{29}$ This was Hobson's mode, but by treating machinery diachronically — as a historical phenomenon — he was also highlighting its contingency as a social and economic factor. Hobson believed that the machine had been determinative for the past and the present but, unlike many of his influential contemporaries, he held that its role in the future was still to be debated and decided, rather than being self-evident or natural. ${ }^{30}$

\section{A STUDY OF MACHINE PRODUCTION}

Hobson's ethicism and his holism are often mentioned as forming his organic conception of political economy; however, it is not always easy to know how this worked in practice. The case of machinery provides a concrete example of what an ethical political economy looks like and why holism was a necessary approach to producing it. If Hobson's concern was to preserve the human element of economic analysis, this meant thinking about what people actually experienced and how they behaved, both at work and after it. This Ruskinian impulse directed attention to consumption as well as production, and demanded some account of the machine, since, to Hobson, the machine appeared to have determined production

\footnotetext{
${ }^{29}$ The most influential of which was Arnold Toynbee's "Lectures on the Industrial Revolution," first published in 1884. See Daniel C.S. Wilson, "Arnold Toynbee and the Industrial Revolution: Science, Political Economy and the Machine Past," History and Memory, 26 (2014): 134-62.

${ }^{30}$ Hobson was decidedly - and importantly in the political and philosophical sense - not a technological determinist. See for example Hobson's book on Ruskin, in which he laments the received wisdom that "industrial destiny" seems "inevitable". J. A. Hobson, John Ruskin, Social Reformer (London, 1898), 230. Contrast this with a contemporary economic thinker expressing the common wisdom that "the system of production is largely prescribed to us, whether we like it or not, by the existing state of physical knowledge and the industrial arts." H.S. Foxwell, "Irregularity of Employment and Fluctuations of Prices," in The Claims of Labour (Edinurgh, 1886), 188.
} 
completely and, indirectly, consumption as well. ${ }^{31}$ Only an analysis that was systematic enough to include these diverse elements, and yet was unconstrained by narrow, disciplinary boundaries could account for the diffuse impact of machinery - and this was what Hobson attempted.

The central statement of Hobson's thinking on machinery comes in The Evolution of Modern Capitalism: A Study of Machine Production. Initially published as part of Havelock Ellis's popular "Contemporary Science Series" in 1894, it was expanded in the course of four editions and was among Hobson's most frequently reprinted books. ${ }^{32}$ In The Evolution of Modern Capitalism, Hobson reprised the classic themes of the machinery question previously posed between 1815 and 1848, addressing the problems of technological unemployment, wages, the working day, skill, working conditions (both physical and psychological), the spatial concentration of factories, monopolies, and product quality, restating them for his own time. ${ }^{33}$ Hobson concluded that while some specific problems associated with machine production had been addressed by the factory legislation that had accumulated since the midcentury, the fundamental difficulties had not been tackled.

Setting out his aims, Hobson claimed that the text was intended as a bridge between "the wider philosophic survey of treatises on Social Evolution and the special studies of modern machine-industry contained in such works as Babbage's Economy of Manufactures and Ure's Philosophy of Manufactures." The principle of evolution was employed in order to

\footnotetext{
${ }^{31}$ This perspective was in place from Hobson's very first book, in which he criticized the neglect of consumption by classical economists from J.S. Mill onwards: The Physiology of Industry, 7. To hold that machinery had determined the course of history in the past is not necessarily to believe it must continue to do so in future.

32 J. A. Hobson, The Evolution of Modern Capitalism: A Study of Machine Production (London, $1926 ; 1894)$. All further references are to the first edition of 1894 unless stated otherwise. The book was being reprinted as late as 1965 and, according to J.R. Commons, was widely used as a university textbook and "had become more authoritative than Marx". Fiona Maclachlan, "J.A. Hobson and the Economists," Journal of Post Keynesian Economics 25, no. 2 (2002): 298.

${ }^{33}$ Berg, Machinery Question.
} 
mark the subject matter as one "in process of organic change" as opposed to a static phenomenon. Hobson explained his focus on machines in this way:

in bringing scientific analysis to bear upon phenomena so complex and so imperfectly explored, it is essential to select some single clearly appreciable standpoint, even at the risk of failing to present the full complexity of forces in their just but bewildering interaction. ${ }^{34}$

Hobson presented his subject as "bewildering" and "complex," while his claim that it had been "so imperfectly explored" reflected the dearth of existing analyses of technology. Despite Britain being in the midst of its second industrial revolution there was, in 1893, no obvious work to which one could turn for an account of machinery as a social and economic phenomenon. It was for this reason that he signaled Babbage and Ure as his points of reference and so indicated his continuity with the machinery debates of the 1830 s. Despite these works being sixty years old at the time Hobson wrote this text, they remained the place for him to begin. ${ }^{35}$

By using the phrase "machinery as a factor in industrial evolution," Hobson was not merely setting out evolution as a favored mode of analysis, so typical of this period among social investigators, but he was also following the founders of economic history - W.J. Ashley and William Cunningham - in applying the idea of evolution specifically to industry. ${ }^{36}$ This phrase also allowed Hobson adroitly to allude to Arnold Toynbee's idea of

\footnotetext{
${ }^{34}$ Hobson, EMC, v.

${ }^{35}$ Hobson was aware of Marx's Capital, to which he referred several times in the course of the book, but chose not to invoke it at the outset. Hobson also mentioned a more recent history of the cotton industry by Schulze-Gaevernitz; this was a work in line with the trend widely noted at the time, that the best analyses of the first British Industrial Revolution were being produced by foreign writers. Although well known in Fabian circles, this book was not yet published in English at the time Hobson was writing.

${ }^{36}$ William Cunningham, The Growth of English Industry and Commerce (Cambridge, 1921; 1882); W.J. Ashley, The Economic Organisation of England: An Outline History (London, 1914). For the
} 
the "Industrial Revolution" - a concept which was at this time beginning to take hold as a recognized historical framework - while simultaneously rejecting its general validity. Like Ashley and Cunningham, Toynbee himself had been ambivalent about the idea of revolution: an idea which appealed to publishers more than it did to historians who sought - then as now - to question its fitness as a model for change. In this sense, Hobson can be seen as participating in a process through which the Toynbean tradition of industrial historiography was gradually refined, but which did not produce any disciplinary legacy in the twentieth century. Like some of his predecessors, Hobson sought to assimilate a diverse range of elements into one narrative, although his ambition was more singular. Hobson wanted to make sense, specifically, of how machines had shaped working conditions, economic prospects, and social life; but, unlike the historians, Hobson's story would be told in the language of ethics. The resulting text takes an unusual form, combining history and economics, and is thus marked by inevitable strengths and weaknesses. Remarking on this eclecticism, critics have questioned the extent to which Hobson was truly a historian. ${ }^{37}$ However, this is to misapprehend the intent of an ethicist who was polemical as much as analytical, and who was therefore happy to synthesize the work of others in assembling his case rather than taking the disinterested and nuanced approach later valorized by professional

classic account of how evolution appeared more widely, see John Burrow, Evolution and Society: A Study in Victorian Social Theory (Cambridge, 1966).

${ }^{37}$ For example, Colin Matthew chastized Hobson on this count, appearing to regret that The Evolution of Modern Capitalism was not, like the work of Beatrice Webb, a history based on primary research. H.C.G. Matthew, "Hobson, Ruskin and Cobden," in Reappraising J.A. Hobson: Humanism and Welfare, ed. Michael Freeden (London, 1990). Such a standard of assessment begs the question of what would be the appropriate method for a study such as Hobson's, while failing to recognize the obverse fact that Beatrice Webb's method was, in other ways, implicitly Hobsonian. While Hobson and the Fabians' politics increasingly diverged (See Noel Thompson, "Hobson and the Fabians: Two Roads to Socialism in the 1920s," History of Political Economy 26, no. 2 (1994): 203-20), their thought nevertheless displayed "the same insistence on the unity of the social studies; the same refusal to recognize as valid a separate body of economic theory based on abstractions, the same determination to study directly the practical behavior of persons and institutions, where the 'economic' appears only as an aspect of a working unity spreading out over the whole of social life." G. D. H. Cole, "Beatrice Webb As an Economist," in The Webbs and their Work, ed. Margaret Cole (London, 1949), 281. For other criticisms, see also Donald Winch, “A Composition of Successive Heresies': The Case of J. A. Hobson," in Wealth and Life. 
historians. The final chapters of the book, which discuss the nature of the industrial city and the role of women in the workplace, would have been unlikely to find space in many orthodox works of economics; and similarly, Hobson's creation of a single narrative extending from premodern history to an analysis of the Standard Oil Company, is an example of the unitary vision which a political account of machines has demanded but rarely found, in the 1890 s as in the present.

Hobson's key insight in The Evolution of Modern Capitalism was to reconnect the dissenting theory of underconsumption to the rise of machine production. A founding axiom of orthodox economics was Say's Law, according to which production and consumption would tend to a happy state of equilibrium in which underconsumption was a theoretical impossibility. When this general theory emerged in the earlier nineteenth century it had been contested by various figures but nevertheless became a central precept of economic science. ${ }^{38}$ Hobson, on the other hand, saw underconsumption as a constant risk in a machine-based system of laissez-faire and, in particular, as the cause of the economic stagnation Britain had suffered to different degrees for two decades. The symptom of underconsumption was in what Hobson considered the unproductive surplus; that is, excessive profits neither reinvested in physical plant nor spent on consumption. While the notion of the surplus has been rightly highlighted as the signal feature of Hobson's brand of underconsumptionism, his account of the origins of surplus has not been discussed. ${ }^{39}$ Hobson's controversial first book, The Physiology of Industry (1889), had outlined the demand-side mechanisms through which underconsumption caused stagnation (e.g., oversaving); his most famous book, Imperialism (1902), went on to describe the political outcome of this phenomenon by accounting for

\footnotetext{
${ }^{38}$ This so-called law, named after Jean-Baptiste Say, had originally arisen in response to fears about machinery. Despite being challenged by Robert Owen and Malthus, among others, the question remained unresolved.

${ }^{39}$ Alan Lee, "A study of the social and economic thought of J.A. Hobson," (Ph.D, University of London, 1970).
} 
Britain's overseas expansion in terms of its need to dispose of surplus products. In the period between Hobson's writing of these two landmark books, underconsumption was brought into stark relief by the related - but analytically distinct - phenomenon of overproduction in Britain's factories. Considering this first decade of Hobson's career within this framework can help illuminate the emergence of his political analysis of machinery. It was in The Evolution of Modern Capitalism, written roughly halfway between The Physiology of Industry and Imperialism (in 1893-94), that Hobson produced an account of machinery that blamed it for exacerbating this anomalous feature of capitalism. The idea that an economy could simultaneously underconsume and overproduce was anathema to neoclassical economists and, yet, Hobson saw this double scourge as both the cause of British economic depression and also the motivation for the nation's ruinous overseas adventures. ${ }^{40}$

On the home front, Hobson could not have been clearer: machine production was both "the efficient cause of industrial disease" and the only way to analyze it. ${ }^{41}$ Despite its potential benefits, machinery had precipitated the economic depression of the 1890s and was the concrete element in Hobson's larger underconsumptionist schema. Although central to his notion of the surplus, his critique of political economy and, eventually, of imperialism, the idea of the machine has not figured in accounts of Hobson thought. This is all the more puzzling given that The Evolution of Modern Capitalism: A Study of Machine Production was among Hobson's most visible works and was constantly updated in the light of new

\footnotetext{
${ }^{40}$ Peter Cain disputes Norman Etherington's claim that the American industrial theorist H. Gaylord Wilshire's 1901 writings were the decisive influence in coalescing Hobson's anti-imperialist position on various grounds. A consideration of Hobson's machine writings gives succor to Cain's view, but for the reason - not mentioned in that discussion - that Hobson could already account for overproduction as the result of machinery, and so the building blocks for the pivotal argument advanced in his seminal "The Economic Taproot of Imperialism" and subsequently were already in place before Hobson ever encountered Wilshire. Norman Etherington, "The Capitalist Theory of Capitalist Imperialism," History of Political Economy 15, no. 1 (1983): 38-62; Peter J. Cain, "Hobson, Wilshire, and the Capitalist Theory of Capitalist Imperialism," History of Political Economy 17, no. 3 (1985): 455-60.

${ }^{41}$ Hobson, Evolution of Modern Capitalism, 182.
} 
theoretical and empirical data. ${ }^{42}$ The Evolution of Modern Capitalism was frequently

mentioned in Hobson's obituaries, yet, in modern commentaries, the book is often passed

over, while its true focus - machinery - is elided by the frequent removal of its crucial subtitle. ${ }^{43}$ The Evolution of Modern Capitalism is vital for understanding Hobson's trajectory and restoring the book's centrality helps makes sense of Hobson's otherwise inexplicable assessment of it years later: "as I look back upon it, I find that it contains in germ nearly all the departures from economic orthodoxy which my subsequent writings disclosed."44

Hobson came to write the book because the Fabian William Clarke, originally commissioned by Havelock Ellis, was unable to fulfill the commitment and passed it on to him instead. ${ }^{45}$ If one infers from this piece of good fortune that machinery was an incongruous topic for Hobson to have taken on for a monograph, this would be a mistake: having written a detailed article on the subject the previous year, he was perfectly primed. ${ }^{46}$ Hobson had been asked to write a book on capitalism and could have taken any of several approaches rather than focus on machines. However, during the year in which he was drafting the book, Hobson had become increasingly active at the South Place Institute, giving and attending various lectures and discourses at what was, perhaps, the liveliest intellectual space in 1890s London. The urgent question of industrial unrest - set against the backdrop of the ongoing Royal Commission on Labour - had led the Institute to devote their Sunday

\footnotetext{
${ }^{42}$ For example, in his complete endorsement shortly after its publication of Werner Sombart's Der Moderne Kapitalismus, which Hobson outlined for English readers in what became the first chapter of Evolution of Modern Capitalism from its second edition onwards in 1906.

${ }^{43}$ The book is neither mentioned in Michael Freeden's introduction to Hobson's autobiography, nor excerpted in his Hobson: A Reader (London, 1988), while the elision is further entrenched in a recent three-volume edition, in which the question of machinery is not mentioned once and The Evolution of Modern Capitalism hardly at all: John C Wood and Robert D Wood, ed., J. A. Hobson: Critical Assessments of Leading Economists, 3 vols. (London, 2003). Much of Lenin's criticism (i.e., that Hobson did not treat agriculture) may be attributed to the dropping of the precise sub-title in the Russian translation, suggesting a less-focused intention than was, in fact, the case, V. I. Lenin, "Review," Economica, 15 (November 1925): 362-64.

${ }^{44}$ Hobson, Autobiography, 38.

${ }^{45}$ Havelock Ellis, My Life (London, 1940), 237.

${ }^{46}$ Discussed further in section IV, below. J. A. Hobson, "The Influence of Machinery Upon Employment," Political Science Quarterly 8, no. 1 (1893): 97-123.
} 
afternoon lecture series of 1893-4 to the theme "workers on their industries." 47 Although intended to provide a forum for "possible remedies for their grievances," each week - on forty-eight consecutive occasions - representatives of different trades, from bricklayers to typesetters to engineers, reported gloomily on the effects of machinery on their particular industries. Notwithstanding the air of defeatism, the series was deemed to have been a success, occupying the Institute for two years and being much better attended than the contemporaneous evening lectures on the growth of British imperialism. As well as being topical, the lectures provided a rare set of first-hand testimonies presented with a singular focus on the means of production. ${ }^{48}$ It is almost certain that Hobson would have attended this series while composing The Evolution of Modern Capitalism. Given that he gave several discourses himself during the course of the series - the South Place equivalent to a Sunday morning sermon - he would have been in the same building just before the weekly lectures began. It is easy to imagine these discussions about machinery percolating into his thought, and shaping his conviction that it was through this particular lens that the evolution of capitalism should be viewed.

In his earlier book The Problems of Poverty (1891) Hobson included a short section concerning Alfred Marshall's belief in the positive influence of machinery. At that time, although Hobson noted certain of the costs incurred in the division of labor, he accepted the substance of Marshall's claims for machine work and was especially positive about its impact on consumers. ${ }^{49}$ In the course of the following year two books on machinery were published by R.W. Cooke-Taylor and Joseph Shield Nicholson that sharpened Hobson's perspective. A year before publishing The Evolution of Modern Capitalism, Hobson rehearsed his

\footnotetext{
${ }^{47}$ Report of the South Place Ethical Society Committee, 14-16, 1893-4, South Place Ethical Society, Conway Hall Archives.

${ }^{48}$ South Place Terms ran from October to March and the range of topics covered was extraordinarily wide. A small selection were published as a book the following year: F. W. Galton, Workers on their Industries (London, 1895).

${ }^{49}$ J. A. Hobson, Problems of Poverty: An Inquiry Into the Industrial Condition of the Poor (London, 1891), 45.
} 
theoretical claims in a polemical article which placed Marshall, Nicholson and Cooke-Taylor into a productive disagreement and that allowed him to elaborate his own assessment of machinery. Cooke-Taylor was the son and namesake of a famous free-trader of the 1840s and had become HM Inspector of Factories. This expertise led him to author several volumes on the factory system, the latest of which Hobson had read and which he found implausibly optimistic. ${ }^{50}$ Nicholson, on the other hand, was an established academic economist whose essay about machinery can be seen to have shaped Hobson's views most profoundly on the subject.

\section{JOSEPH SHIELD NICHOLSON}

It is only by tracing the influence of Nicholson that one can make sense of Hobson's trajectory back to the machinery question. Joseph Shield Nicholson (1850-1927) was Professor of Political Economy at Edinburgh and a disciple of his adopted country's bestknown economist, leading The Times to say at his death that "He knew his Wealth of Nations like the Scottish peasant knows his Bible, and believed in it almost as thoroughly.", Nicholson was awarded the first ever Cobden Prize - named in honor of the free-trader Richard Cobden - for his 1878 essay on machinery which was reissued as a book in 1892 and gained widespread attention. ${ }^{52}$ Nicholson's was the first economic study of machinery published in English during the 1890s and was Hobson's most significant source on the topic. Whereas "many writers of repute had clearly and fully discussed the good effects of

\footnotetext{
${ }^{50}$ Richard Whately Cooke-Taylor, The Modern Factory System (London, 1891).

${ }^{51}$ Times, 13 May 1927, 11.

52 J. Shield Nicholson, The Effects of Machinery on Wages (London, 1892). All references are to the 1892 text. Positive reviews included L. L. Price, "Review," The Economic Journal 3, no. 9 (1893): 91-92.
} 
Machinery, hardly one had noticed the evils inherent in its use." ${ }^{, 53}$ The problems caused by machinery may have been obvious to many, but had not been analyzed in detail by those within the orthodox tradition of political economy. Nicholson was therefore offering a corrective to the received view articulated by the French political economist Michel Chevalier, whom he claimed "writes in an optimist view which appears to me unwarranted." 54 The political contours of this debate are not straightforward to navigate with twentieth-century categories of left and right that, in any case, are not reliable predictors of attitudes to technological questions. The British reception of Marx and Engels remained patchy at this time and, notwithstanding Marx's critique of the division of labor under capitalism, a position on the political left would by no means entail a critique of machinery per se ${ }^{55}$ Attitudes to machinery among socialists were as diverse during the period - from William Morris to the technocratic Fabians - as they were among economic conservatives. Hobson was neither a socialist nor a conservative and it is instructive that he was agnostic with regard to the market so long as the role of machinery could be radically redefined within it. ${ }^{56}$ For a mainstream economic thinker such as Nicholson who subscribed to free trade, the question of machinery was potentially a vexing one since it threw up simultaneously radical and orthodox conclusions for which there were few precedents within the received corpus of political economy. This was precisely the sort of challenge that appealed to Hobson.

Nicholson's investigation concluded that the greatest evils of machinery were the irregularity of work and the fluctuation of wages that were "the inevitable result" of a

\footnotetext{
${ }^{53}$ Nicholson, Effects of Machinery, v.

${ }^{54}$ Ibid., 6; Michel Chevalier, Cours d'économie politique fait au Collège de France, 3 vols. (Paris, 1855).

${ }^{55}$ On Marx in Britain, see E. J. Hobsbawm, "Dr. Marx and the Victorian Critics," in Labouring Men: Studies in the History of Labour (London, 1964).

${ }^{56}$ For Hobson's ongoing belief in the power of the market as contrasted with Fabian skepticism, see Noel Thompson, "Hobson and the Fabians," who cites Hobson's line (during his intervention in Labour Party debates over the living wage) that "machinery must be dethroned." This comment, however, can only be decoded in light of Hobson's long-standing engagement with the machine question. Hobson and the Fabians agreed that the actually existing market was anarchic and unproductive, but for fundamentally different reasons.
} 
machine-based economy out of control. Yet despite such claims, Nicholson's essay is curiously ambivalent. The relentlessly negative detail of his own discussion does not appear to diminish the overall tenor of the narrative, which is governed by the assumption that the introduction of machinery is usually beneficial. This discrepancy can be explained by the different types of material included in the analysis and by the different explanatory levels on which they operate. On the one hand, Nicholson reported the enormous forces at work during mechanization, and the statistics of European industrial growth he quoted were testament to the sublime power of machines to change whole economies. Quoting Chevalier's figures with relish, he claimed that in 1840 one man plus a machine could do the same amount of cotton spinning which in 1769 would have taken 320 men. By 1855, the French economist had recalculated this to a ratio of 700 to one. The production of cotton paled into insignificance, according to Nicholson, when compared with the impact of steam power in general. A recent calculation by a German economist had shown that the total steam power in the world was equivalent to the force of twenty-five-million working horses. However, this machine force was generated without the need for any food, except that of the miners digging the coal, whose tiny energy consumption as compared with that output by the coal they produced was in a ratio of one to a thousand. ${ }^{57}$ Such awesome transformations were recounted in a range of contemporary texts and can be seen contributing to the more general discourse of "fear and wonder" which helped manufacture consent for new technology. ${ }^{58}$ However, the focus of such discussions tended to remain at a macro-level and had no way to incorporate the local impacts of mechanization, which were only registered in more subjective idioms. This representational problem perhaps explains the sudden shift in register that occurs in the middle of Nicholson's essay when he suddenly inserts the following lines of verse:

\footnotetext{
${ }^{57}$ Michel Chevalier, Cours d'économie politique 1: 319 .

${ }^{58}$ Rieger, Technology and the Culture of Modernity.
} 
They look up with their pale and sunken faces,

And their looks are sad to see,

For the man's hoary anguish draws and presses

Down the cheeks of infancy;

$[\ldots]$

And all day the iron wheels are droning,

And sometimes we could pray,

'O ye wheels' (breaking out in a mad moaning)

'Stop! be silent for to-day!'”

Although unattributed, these lines would have been familiar to many readers as Elizabeth Barrett Browning's 1843 poem about child labor, "The Cry of the Children."59 The absence of personal testimony from traditional forms of economic discourse may have invited Nicholson's somewhat gauche use of poetry to indicate that all was not well in the factories. The final line quoted, in which the children plea for a stop to the machines, is a strange intervention into a prize-winning essay in Cobdenite political economy, and demonstrates the tension between different approaches to industrial questions existing within a single text. Nicholson's essay exemplifies the more general trend in which the discussion of machinery bifurcated into the incommensurable languages of technical economics on the one hand and Romantic laments on the other. Although writing before the systematic study of industrial health or fatigue, the assumed progress represented by higher wages and factory legislation appears untainted by the accumulating evidence of the "pulmonary mischief" and other ills

\footnotetext{
${ }^{59}$ Lines 25-29 and 85-89: an extract of those cited in Nicholson, Effects of Machinery, 46-47.
} 
suffered by factory workers. ${ }^{60}$ Recognizing the difficulty of assimilating such discrepant data, it was on two points in particular that Hobson would extend Nicholson's analysis in a skeptical direction. First, any increase in wages was worthless if it cost workers time and energy since they would be left unable to benefit from the increase. Second, any evaluation of machinery depended on the scale of the analysis. That is to say, it was not fair to compare the benefits at a global level, with the costs at a local one. ${ }^{61}$ If the only expression of the costs of machinery was to be found in poems and laments, then this was not the basis for a proper analysis, and still less could it contribute to social reform.

In a passage that Hobson read very closely, Nicholson sought to explore the structural properties of the machine economy, beginning with the effects of improved transport and communication. An analogy with meteorology was often assumed to hold by economists: just as air moves between areas at different pressures, capital and labor were seen to move accordingly to the locations where they would operate most profitably. ${ }^{62}$ In reality, however, Nicholson claimed that such a comparison was misleading since, with respect to the new facility of information, labor was much less mobile than capital: "it is, I think, clear that the capitalist has gained by far the most. Of all markets the labour market is the least organized". Whereas the capitalist considers a range of external facts, from rumors of war to speculation, crop yields and more, "hardly one of them is considered even by the most intelligent workmen before its effect is felt. Thus Capital has taken full advantage of its increased means

\footnotetext{
${ }^{60}$ This pungent phrase was borrowed from G. Phillips Bevan, The Industrial Classes and Industrial Statistics (London, 1877), 18, cited by Nicholson at p. 82, while his information on cotton came from a recent report in Cotton Factory Times, 5 February 1892, cited at 74-76.

${ }^{61}$ This methodological problem can affect historians of material culture in general; the ways in which the choice of analytical scale can determine the varieties of explanations arrived at is discussed by Thomas J. Misa, "Retrieving Sociotechnical Change From Technological Determinism," in Does Technology Drive History?: The Dilemma of Technological Determinism, ed. Merritt Roe Smith and Leo Marx (Cambridge, MA, 1994).

${ }^{62}$ Nicholson cites Cliff Leslie as an example on this point: "The movement of agricultural wages in Europe," Fortnightly Review, 21 (1 June 1874): 705-19.
} 
of obtaining knowledge, Labour scarcely at all." ${ }^{, 63}$ To Nicholson, this fact vindicated Adam Smith's claim that "man is of all baggage the most difficult to be transported." ${ }^{\prime 64}$ Nicholson was fond of this phrase, which he used on several occasions and took to be a truism of industrial relations. ${ }^{65}$ It was, however, a slight misquotation, as Smith actually used the word "luggage" rather than "baggage" in the original passage. ${ }^{66}$ Nicholson's influence can thus be gauged by the fact that his error in quotation was introduced into the work of several other writers - including Hobson - who went on to quote Smith but with Nicholson's exact mistake. $^{67}$

Nicholson sought to relate the specific damage done to workers to a more panoramic view of the machine economy with the use of an organic metaphor. A century earlier, Smith had warned that it would be unwise for Britain to rely on too few outlets for its products: the dependence on colonial markets, for example, had dangerously skewed the economy. "Great Britain resembles one of those unwholesome bodies in which some of the vital parts are overgrown, and which, upon that account, are liable to many dangerous disorders scarce incident to those in which all the parts are more properly proportioned." ${ }^{68}$ Smith wrote this passage with regard to colonial policy, but for Nicholson it could now be read as directly relevant to the dangers attaching to machinery, which served to concentrate industry into an unbalanced monolith, exposed to even worse fluctuations than those caused by the colonial

\footnotetext{
${ }^{63}$ Nicholson, Effects of Machinery, 110-11.

${ }^{64}$ Ibid., 103.

${ }^{65}$ For example, see J. Shield Nicholson, Examination of the Crofters' Commission Report (Edinburgh, 1884), 17.

${ }^{66}$ Adam Smith, An Inquiry Into the Nature and Causes of the Wealth of Nations, ed. Edwin Cannan (Chicago, 1976), bk1, ch8, §30.

${ }^{67}$ Other examples include Paul H. Douglas, "The Economic Theory of Wage Regulation," The University of Chicago Law Review 5, no. 2 (1938): 184-218, at 214. Ironically, when Hobson re-used this phrase - years later - it was to make the opposite point. J. A. Hobson, International Trade: An Application of Economic Theory (London, 1904), ch4, §1.

${ }^{68}$ Smith, Wealth of Nations, bk4, ch7, §129.
} 
trade. With half-a-million people by 1881 working in factories producing cotton, any small fluctuation in its price was potentially devastating. ${ }^{69}$

Nicholson argued that while the machinery of communication had distributed markets around the world, it had also bound the economy more closely together and exacerbated the problem.

The enormous development of steam communication and the spread of the telegraph over the whole globe have caused modern industry to develop from a gigantic starfish, any of whose members might be destroyed without affecting the rest, into a $\mu \varepsilon ́ \gamma \alpha \zeta \tilde{\omega}$ ov which is convulsed in agony by a slight injury in one part. ${ }^{70}$

The Greek " $\mu \varepsilon \dot{\gamma} \alpha \zeta \tilde{\omega} o v$ " in this passage means literally "large animal" and was intended to indicate the macrocosmic organic unity of the global economy of the late nineteenth century. ${ }^{71}$ Economic writers - from the eighteenth to the twenty-first century - have frequently adopted natural scientific metaphors to articulate their normative visions. ${ }^{72}$ For Nicholson, it was preferable that the economy resemble a starfish, admired for its durability, rather than a large animal, which was vulnerable to the smallest attack on any part of its body. In his essay, therefore, the idea of the machine emerges as unstable, its valuation shifting throughout: at times Nicholson appears to have been as awed by mechanization as many of his contemporaries, convinced of its glorious inevitability, while at others he abhorred its effects in displays of stereotypical Romanticism. As well as advancing a view of the economy as organic and highlighting its tendency to concentrate capital, Nicholson's

\footnotetext{
${ }^{69}$ B. R. Mitchell and Phyllis Deane, Abstract of British Historical Statistics (Cambridge, 1962), 188.

${ }^{70}$ Nicholson, Effects of Machinery, 117.

${ }^{71}$ For the origins of this image in Greek thought, see the discussion of Aristotle's Physics in George Boas, The History of Ideas: An Introduction (New York, 1969), 220.

${ }^{72}$ Philip Mirowski, Natural Images in Economic Thought: Markets Read in Tooth and Claw (Cambridge, 1994).
} 
essay hinted at a holistic approach to the machinery question that gave Hobson his point of departure. $^{73}$

\section{EMPLOYMENT: QUANTITY}

Hobson's 1893 article “The Influence of Machinery upon Employment” was his first serious engagement with machinery and formed the basis for all of his subsequent writings on the subject. Unlike Nicholson, who had only focused on wages, Hobson - whose article was published in Political Science Quarterly - addressed the influence of machinery on employment in general. Hobson had already written about the irregularity of machine work in 1891, but Nicholson's account allowed him to advance a more global understanding of how the influence of machinery was to make all forms of work more irregular. ${ }^{74}$ Nicholson's proposed solution was for moral renewal in root and branch, as he appealed to captains of industry to show noblesse oblige by increasing wages in order that workers might be better acculturated. ${ }^{75}$ For Hobson this was no solution because it failed to compensate workers for the loss of their most precious asset, namely, time. In any case, machinery had always tended towards the opposite: decreasing wages while alienating workers from their culture. As far as Hobson was concerned, these tendencies demanded an ethical debate about the rightful place of machinery, which had yet to be conducted.

Hobson began with one of Nicholson's themes and turned it into the framing question for his investigation: does machinery really increase the overall amount of employment, as its apologists argue? Orthodox economics appeared to produce a paradox: "a new machine

\footnotetext{
${ }^{73}$ Hobson was critical of those with whom he otherwise agreed, but who did not fully appreciate the organic nature of the economy: "Review of Henry Dyer," International Journal of Ethics 6, no. 1 (1895): 127-29.

${ }_{75}^{74}$ Hobson, Problems of Poverty.

${ }^{75}$ Nicholson had taken his epigraph from Brentano: "Die lohnfrage ist eine culturfrage," [sic] implying that higher wages entailed higher culture.
} 
always displaces and throws out of employment a certain amount of labor [...] What is meant, then, by the statement so frequently made, that machinery gives more employment than it takes away?"76 Hobson examined this counterintuitive (yet orthodox) claim that although the introduction of machines might cause a number of jobs to be lost, the overall number of jobs would always rise due to the expected fall in prices. ${ }^{77}$ Hobson pointed to the enormous assumption on which this claim was made - that the efficiencies achieved using machines would result in lower prices rather than simply swelling profits - and chose to open his argument by merely bracketing the problem, which implicitly undercut the foundations on which the pro-machine orthodoxy was built. There was no guarantee - or indeed any evidence - that capitalists passed the savings achieved through mechanization on to their customers rather than keeping them for themselves.

To consider how far prices stimulated demand in theory, Hobson took Alfred Marshall's notion of the flexibility of demand as the most sophisticated analysis of this relation available. However, a problem immediately arose: Marshall's theory required an "extremely intricate knowledge of the circumstances of each case." ${ }^{78}$ Applied to more than one class of manufactured good, this calculation would yield vastly discrepant results. Each case of machine production and consumption was so different as to render a general theory improbable. Hobson concluded sharply that

It is therefore impossible to argue a priori that the ultimate effect of machinery must be an increased demand for labor, and that the labor displaced by machinery will be

\footnotetext{
${ }^{76}$ Hobson, "The Influence of Machinery Upon Employment," 97. American spellings in original.

${ }^{77}$ This claim was repeatedly made by economists, for example, Leone Levi, Work and Pay: Or, Principles of Industrial Economy (London, 1877), 29; Hobson disputed this in EMC, 222ff.

${ }^{78}$ Hobson, "The Influence of Machinery Upon Employment," 98.
} 
directly or indirectly absorbed in forwarding the increased production caused by machinery. $^{79}$

Hobson was skeptical of general claims about the benefits of machinery since these were supported neither by detailed individual studies nor by historical investigations. A historical account of the Industrial Revolution explained how Britain came to be in its leading position, but the British experience was a special case that did not admit of generalization and "cannot be taken as a measure of the normal effects of the application of machinery."

Hobson cited census data to show that both the relative and the absolute number of people employed in manufacturing had actually fallen from the mid-nineteenth century, while the number of machines had continued to increase. ${ }^{81}$ This was the only available measure of the overall trend, and Hobson found no evidence to support Marshall's claim that machinery increased employment; rather, it seemed as though the opposite was the case. Certain growth areas such as distribution had witnessed an absolute rise in employment over the same period. However, while the total amount of distribution had increased, the number of those employed had not risen proportionately. Machines, therefore, caused a relative decline in employment for the quantity of goods being distributed.

To help make sense of these trends Hobson introduced an original distinction to thinking about machine work, based on the "proximity to the machine" of different workers, as exemplified by the cases of railways and shipping. Machinery played different roles in these two industries, being much more integral to the operation of a steamship than it was to that of a railway. Only a handful of workers, such as engineers, stokers, and guards were "in close direct association with the machine," while an attendant "army" of other workers were engaged indirectly by the railway, from clerks to ticket collectors to navvies and plate

\footnotetext{
${ }^{79}$ Ibid.

${ }^{80}$ Ibid., 99.

${ }^{81}$ Ibid., 99-102, also using the data gathered by Charles Booth.
} 
layers. ${ }^{82}$ For this reason, total railway employment actually increased proportionally faster than the total mileage of the system. Steamships, on the other hand, grew in size and developed in tandem with the influence of machinery. New engines, bigger ships, and more streamlining allowed a greater tonnage to be carried with relatively fewer people employed. In half a century, total tonnage had increased four-fold, but the attendant increase in employment was less than three-fold.

This led Hobson to the general finding that in the trades examined machinery had caused a decrease in employment relative to production. Even in associated industries such as transport, "the increase in employment is in inverse proportion as machinery is introduced $[\ldots]$ as a dominating factor." In other words, if machinery became integral to a growing industry, employment increased at a slower rate than elsewhere, and any displaced labor found employment in areas which were "less subject to machinery." Insofar as the effects of machinery had been registered at all, therefore, Hobson concluded "that the net influence of machinery is to diminish employment so far as those industries are concerned into which machinery directly enters, and to increase the demand in those industries which machinery affects but slightly or indirectly." 83 Nicholson's argument had focused on the effects of machinery on the regularity of employment, and it was to this that Hobson now turned. Orthodox economists claimed that disturbances to employment caused by machinery should be seen as temporary. This idea had already been criticized by Nicholson, and Hobson concurred: with added incredulity, he reminded readers that "the loss of employment may be only 'temporary,' but as the life of a workingman is also temporary, such loss may as a disturbing factor in the working life have a considerable importance." ${ }^{\prime 84}$ Hobson now went

\footnotetext{
${ }^{82}$ Ibid., 102-03.

${ }^{83}$ Ibid., 104. Hobson remarked in an aside that the most dramatic effect of machinery on employment had been in agriculture. He claimed that this had scarcely been addressed because of the prohibitive complexity of the calculations, but that it was obvious that English agriculture had been decimated by the cheap transportation of foreign produce.

${ }^{84}$ Hobson, Evolution, 237.
} 
beyond Nicholson's focus on the initial impact of machinery at the moment of its inception to examine the ongoing issue of the "normal effects of machine production."

The fact that employers had often invested large sums of capital in new machinery meant that it was in their interest to keep their factories running consistently. This helped them achieve the greatest return on their investment and seemed to promise regular employment for workers. However, the result of new machinery was, in fact, the opposite. Citing Nicholson, Hobson claimed that machine-made commodities were subject to the greatest fluctuations in prices because of the great quantity of production. This, in itself, led the levels of wages and employment to fluctuate more than ever before, and was an effect compounded further because these were the only controllable variables remaining in a production process in which an increasing proportion of capital was being fixed in the form of machinery. Extending Nicholson's conclusions, Hobson could now account for the effects of machinery as a whole:

while it is the interest of each producer of machine-made goods to give regular employment, some wider industrial force compels him to irregularity. What is this force? It is uncontrolled machinery. In the several units of machine production, the individual factories or mills, we have admirable order and accurate adjustment of parts; in the aggregate of machine production, we have no organization, but a chaos of haphazard speculation. "Industry has not yet adapted itself to the changes in the environment produced by machinery." That is all. ${ }^{86}$

While individual machines (and their owners) may have operated productively according to a comprehensible internal logic, the net effect of all of the machines was another thing entirely. When taken together as a whole, machines ran amok: they introduced chaotic, unpredictable

\footnotetext{
${ }^{85}$ Hobson, "The Influence of Machinery Upon Employment," 105.

${ }^{86}$ Hobson, Evolution, 238.
} 
outcomes that nonetheless determined markets and consequently employment. Anticipating the skepticism of his readers, Hobson said they might rightly wonder how machines could be responsible for such fluctuations. It was at this point in the argument that Hobson introduced the phenomenon of overproduction, presented within the larger framework of his theory of underconsumption.

While orthodox economists denied the very possibility of general overproduction since they held that goods would always be exchanged - businessmen, according to Hobson, found that the facts suggested otherwise. When markets were "congested with goods that remain unsold," causing prices to fall, Hobson asked "Would it not be better for economists to recast their theory, so as to be in harmony with facts?"87 The history of economic thought shows that to stipulate an upper limit to production or consumption has been unorthodox: to deny Say's law, as Hobson did by asserting the simultaneous existence of both overproduction and underconsumption, marked his card as a heretic. ${ }^{88}$ The initial conceptualization of these two phenomena had occurred with the earlier onset of machine production around 1800 and, for Hobson, pointed to similar macroeconomic problems in the 1890s. Scholars of underconsumptionism have rarely connected the theory to later discussions of machine production. Yet, the existence of de facto superabundance appears implicitly in ideas of underconsumption from their beginnings. ${ }^{89}$

According to Hobson, machinery had broken the essential link between supply and demand, making it impossible to manage and regulate production effectively. In a historic shift, machinery introduced a new species of glut, independent of the trade cycle.

\footnotetext{
${ }^{87}$ Hobson, "The Influence of Machinery Upon Employment," 108.

${ }^{88}$ Hobson, Evolution, 182-83.

${ }^{89}$ Theories of underconsumption first emerged during the Industrial Revolution with Malthus and it was perhaps Hobson's greatest innovation to connect underconsumptionism with imperialism, by way of the "disproportionality" with consumption introduced by the productive capacity of machinery.
} 
When production was slower [...] there was less danger of this big miscalculation, and the corrective forces of industry were more speedily effective. But modern machinery has enormously expanded the size of markets, the scale of competition, the complexity of demand $[. .$.$] Hence machinery is the direct material cause of these$ great fluctuations which bring, as their most evil consequence, irregularity of wages and employment. ${ }^{90}$

This passage helps explain how Hobson came to his macrocosmic vision of a world interconnected by machinery. It was immediately following this passage that Hobson cited Nicholson's description of the world economy as a large animal. The content of this organic metaphor, therefore, derived from his analysis of how machinery destabilized employment. While Hobson would go on to develop macroeconomic perspectives on the business cycle, trade, distribution, and Empire, these early texts place machinery in the foreground. Indeed, Hobson's account of economic change can appear almost monocausal: machinery is often regarded as autonomous and described in the active voice, crystallizing as both the cause and emblem of contemporary economic chaos. Machines produce the irregularity that is characteristic of modernity, and provide the necessary, if not sufficient, conditions for such evils as the formation of trusts, cartels, and, eventually, imperialism. ${ }^{91}$ If the introduction of machinery was to be assessed by political economists in relation to the quantity of employment then, to Hobson, the question of its impact remained an open one. The impact of

\footnotetext{
${ }^{90}$ Hobson, "The Influence of Machinery Upon Employment," 108. Part of this passage is cited by Peter Cain in what is the only scholarly reference to Hobson's essay I have been able to find. As already mentioned (above, n21) the centrality of machines is not the focus of Cain's reading, which focuses rather on the general development of Hobson's macroeconomic thinking. Interestingly, Cain's citation of this passage begins in the same place as the one given above, except it closes with the penultimate sentence. Thereby Cain omits Hobson's concluding remark that follows directly: "Hence machinery is the direct material cause..." Cain, Hobson and Imperialism, 32.

${ }^{91}$ The story of trust formation is included in The Evolution of Modern Capitalism from the first edition, but Hobson updated the book to reflect the importance, respectively, of financial speculation, imperialism, and war in subsequent reissues, revealing his commitment to the analytical lens of the book as late as its fourth edition in 1926.
} 
machinery on the quality of employment, however, raised a further set of issues that Hobson then set out to consider.

\section{EMPLOYMENT: QUALITY}

Despite Adam Smith's insistence that the goal of all productive labor was consumption, economists from J.S. Mill onwards had struggled to accommodate it convincingly within their various schemas, even as they paid lip service to its importance. ${ }^{92}$ And although political thinkers like William Morris had promulgated concepts such as "shoddy" as a criticism of poor quality production, this remained at some distance from an economic analysis. We have seen that from Hobson's point of view machinery encouraged overproduction, but he also believed that it drove a particular form of standardized massconsumption. It was Hobson's belief that cultivating higher forms of consumption among the public would counter the producer-bias of the economy and also result in better forms of work through the nexus of the improved tastes of the consumer. ${ }^{93}$ This line of argument would be developed more fully in Hobson's later and self-consciously Ruskinian works such as Work and Wealth (1914); however, he was already connecting the question of consumption with that of the regularity of employment as early as 1893 .

In "The Influence of Machinery upon Employment," Hobson argued that demand for the goods which are the "necessaries" of life was easy to predict whereas demand for "comforts and luxuries" was whimsical and "less amenable to commercial calculation." The production of "necessaries" was thus ripe for mechanization and had the effect of driving

\footnotetext{
${ }^{92}$ Smith, Wealth of Nations, 1 ; see Hobson \& Mummery, Physiology of Industry, 4-6, for the ways in which Fawcett, Sidgwick, and other later Victorians had not treated it systematically.

${ }^{93}$ See Frank Trentmann, Free Trade Nation: Commerce, Consumption, and Civil Society (Oxford, 2008), $76 \mathrm{ff}$ for the origins of the citizen-consumer.
} 
workers into the less-mechanizable production of luxuries: "unsteady industries [...] which are most exposed to the influences of taste, caprice or changing income." 94 Not only did machines destabilize markets through overproduction, but they also placed greater numbers of workers into the types of jobs that were intrinsically unstable. With little option available to them, the technologically unemployed could be seen turning to the production of "luxuries," which Hobson therefore derided not only for their politico-aesthetic character but for their effects on employment as well. ${ }^{95}$

Hobson claimed that as well as making labor more irregular, the net influence of machinery was to drive labor in three new directions. First, the increasing capacities of machine tools meant that the tasks of making and maintaining machines would eventually become mechanizable themselves. The result would be to leave workers increasingly occupied with the back-room tasks relating to this machine-servicing machinery, with human intervention therefore occurring at an increasing distance from the point of production. While these back-room tasks would be new jobs, there would inevitably be fewer jobs relative to a given quantity of consumption (which was the explicitly stated aim of mechanization).

Second, machinery resulted in a "multiplication of merchants, middlemen and retailers" which did not necessarily benefit the consumer. ${ }^{96}$ The rise of this "distributive work" was something Hobson lamented, as he regarded selling to be a lesser form of occupation than making. ${ }^{97}$ Third, and perhaps more optimistically, Hobson claimed that the rise of machine production would create a countermovement among consumers for non-machine goods. "New wants," claimed Hobson, were created for goods too irregular to admit of machine production. Hobson imagined an avant-garde consumer who would reject the uniformity of

\footnotetext{
${ }^{94}$ Hobson, "The Influence of Machinery Upon Employment," 110.

${ }^{95}$ Ibid.

${ }^{96}$ Ibid., 111.

${ }^{97}$ Hobson, Evolution, 288. This is an early example of Hobson's debt to Ruskin and pre-dates his biography. See e.g., John Ruskin, Fors Clavigera: Letters to the Workmen and Labourers of Great Britain, ed. W. G. Collingwood (London, 1896), II, 409 (Letter XLIV).
} 
standardized goods and drive consumption to evolve along new lines: "so long as individuals desire to satisfy more fully their present wants, and combine to develop new wants forming a higher or more intricate standard of comfort," the loss of employment caused by machinery would be offset by the demand for these new, non-standardized goods. ${ }^{98}$ Hobson's ethics empowered the consumer to reorient the economy and thus provide a potential solution or, at least, a counterweight to the problems arising from machine work.

Having examined these objective effects of machinery, Hobson turned to its subjective effects; that is to say, the experiential quality of labor. Hobson defined the scope of this analysis curtly as "i.e. skill, duration, intensity, etc.," as if these classic parameters of the machinery question would be familiar to his readers. It was a premise widely shared that the main advantage of machine over human labor was in its application of motive force, delivered with greater power and precision. From this it seemed to follow - and indeed it had been argued by economists such as Marshall - that machinery would take over the operation of automatic, monotonous, and exhausting tasks, leaving human labor to do other things instead. ${ }^{99}$ However, Hobson pointed out that even if the labor displaced by machines became engaged in work which is proved to have been less muscular or less automatic by the fact that it is not yet undertaken by machinery, it does not necessarily follow that there is a diminution in the aggregate of physical energy given out, or in the total “monotony" of labor. ${ }^{100}$

The need for such a statement - so apparently obvious - reveals the powerful background assumptions of progress governing the discourse into which Hobson was intervening. The word "yet" reveals Hobson's belief in a higher order of autonomy on the part of machinery.

\footnotetext{
${ }^{98}$ Hobson, "The Influence of Machinery Upon Employment," 111.

${ }^{99}$ Ibid., 112-13.

${ }^{100}$ Ibid., 113 [emphasis added].
} 
As more workers are displaced into less automatic forms of work, he argued, work itself becomes subject to an increasing division of labor and specialization. Once these "higher grades" of labor become routinized in such a way, they too become susceptible to mechanization and so the way is paved for what Hobson called "a new invasion of machinery." 101 This ever-expanding circle of mechanization was endorsed by those seeking greater economies of production, but was viewed by Hobson with suspicion as part of a cycle the inevitability of which did not make it any less pernicious.

Hobson cited the report on cotton factories used by Nicholson to show that new working conditions were as bad as ever, militating against the claims - advanced by Marshall and especially Cooke-Taylor - that the benefits of mechanization would accrue to workers. ${ }^{102}$ Any "saving of muscular or other physical effort afforded by the intervention of machinery" was more than countered by the tendency of bosses to "force the pace" of work and to increase the hours of labor. In a penetrating reading of The Economy of Manufactures, Hobson caught Babbage giving the game away on this point, when he had claimed that machinery affords a check "against the inattention, the idleness, or the knavery, of human agents." ${ }^{103}$ Hobson noted that this new rhythm of the workplace was only made possible by the historical development of "cheap illuminants." The use of artificial lighting in the workplace had removed that barrier to productivity raised by the daily fall of darkness, as "a part of nature's rest is annexed to the working day," disrupting the natural rhythm of day and night. $^{104}$

\footnotetext{
${ }^{101}$ Ibid., 113.

${ }^{102}$ Ibid., 113; 116.

${ }^{103}$ See Charles Babbage, On the Economy of Machinery and Manufactures (London, 1832), 39.

${ }^{104}$ Hobson, "The Influence of Machinery Upon Employment," 114. Issues related to the rhythm, the intensity and the physics of the workplace in the European context are addressed in detail in Anson Rabinbach, The Human Motor: Energy, Fatigue, and the Origins of Modernity (New York, 1990). Contemporary research on the effects of machine work (such as in the work of the industrial psychologist Hugo Münsterberg) were more advanced in Germany, France, and the U.S.A. than they were in Britain, certainly until the 1910s, and the British debates over Taylorism (see below).
} 
Considering the "growing monotony of production" alongside the length of the working day made Hobson skeptical of the supposed benefits of mechanization to the worker, while the prize of increased real wages - adduced by supporters of industrialization - was undermined by the "curtailment of the portion of time in which he figures as consumer.", 105 The worker was thus seen as exhausted from tending machines and having been robbed of the chance to enjoy the fruits of this labor. This dispiriting fate prompted Hobson to reflect on one of the century's most striking lines: J.S. Mill's "somewhat rhetorical verdict" could nonetheless be "almost justified" when he had claimed in 1848 that it was "questionable if all

the mechanical inventions yet made have lightened the day's toil of any human being." ${ }^{106}$ As with Hobson's essay, Mill's infamous line had come in the context of his own reflection into the question of why machinery had delivered such great returns on capital but so few benefits to workers. While not endorsing Mill's pessimistic conclusion, Hobson differed from the received wisdom of many contemporaries in maintaining that the machinery question should at the very least remain an open one. The scale of machinery's impact on the economy was obvious, yet the ways in which it was put to use were not above scrutiny. Almost uniquely, Hobson sought to connect the question of consumption with workers' quality of life, wages, and regularity of work as part of a single, continuous inquiry rather than as separate issues considered in ineffectual isolation.

\section{A MACHINE CORPUS}

Following Hobson's career forward through the years that followed the publication of The Evolution of Modern Capitalism reveals the way in which machinery remained a cornerstone

\footnotetext{
${ }^{105}$ Ibid., 115.

${ }^{106}$ John Stuart Mill, Principles of Political Economy, ed. W. J. Ashley (London, 1909), bk4, ch6, §9.
} 
of his social and political analysis. This consistent focus on machinery was not the only way in which Hobson was unusual: having been blackballed from a university appointment because of his opposition to the neoclassical orthodoxy, he continued his intellectual work outside the academy. ${ }^{107}$ By the second half of the 1890 s Hobson's public profile had increased with journalism and books published on a variety of subjects. London in the $1890 \mathrm{~s}$ was a hotbed of political activism and played host to a number of left-leaning groups: liberal, radical, and socialist. This ferment gave rise to a thriving discourse in journals and societies, in which Hobson became a key figure. Hobson was actively involved with the Fabian Society but found his intellectual niche in the broader church of the Ethical Movement: having attended South Place (discussed above), he went on to play a central role in the production of its primary journal. Hobson joined Stanton Coit as editor of Ethical World shortly after its foundation in 1898 as the journal changed its title to Democracy and then Ethics as it evolved through the 1900s. The aim of the journal was to encourage a science of ethics and, among other things, it regularly treated industrial problems while attacking orthodox political economy.

Hobson had also been involved with the earlier launch of Commonwealth in 1896 . The journal was intended to provide radical, social critique and evinced a form of patriotism rooted in William Blake, who was cited in the first issue. Despite the superficial nostalgia of its Morrisian layout and typography, Commonwealth was explicitly forward looking. Hobson wrote the first article: a direct challenge to what he considered the myopic views of progress offered by writers such as Marshall, who had argued that higher wages would benefit workers and improve their intelligence simply through their contact with new machinery. ${ }^{108}$ In the face of this seemingly naïve optimism, Hobson claimed that

\footnotetext{
${ }^{107}$ Maclachlan, "Hobson and the Economists."

${ }^{108}$ Alfred Marshall, Principles of Economics (London, 1890), 315ff. Although Marshall had conducted detailed research into the working of machinery both in Britain and abroad, the results of
} 
though large sections of the workers have shared this material prosperity [...] The overcrowding of city life is a direct result of the economy of machine production, and the higher rates of wages earned by city work are in the long run a poor compensation for the loss of pure air and wholesome physical surroundings. ${ }^{109}$

In this very first article in a brand new journal of politics, Hobson gave center stage to the paradox of machine production. The question of machinery - its promise contrasted with its actual effects - was seen as the master key to interpreting both the economy and society in general.

The same progressive sentiments motivated those who formed the Rainbow Circle: a dining and debating club that met monthly in London from 1894. This was an elite private sphere in which Hobson could develop his arguments alongside his more public participation with the Ethical Movement. Members of the Rainbow Circle included both eminent and young radicals and liberals, among them a future prime minister in Ramsay MacDonald. After luxurious dinners, members would hear a talk, typically on a question in politics, economics, or ethics, which was then discussed. Hobson was a founding member and spoke at the second meeting, giving a paper entitled "The Economic Deficiencies of the Manchester School," in which he rehearsed his criticism of the orthodox account of "economic man," and argued for the importance of consumption to political economy. ${ }^{110}$ This meeting came shortly after the first publication of The Evolution of Modern Capitalism and so Hobson's interest in consumption can be seen to have developed contemporaneously with his study of machinery.

this work would not be published until much later, in his monumental Industry and Trade (London, 1919).

${ }^{109}$ J. A. Hobson, "The Measure of Poverty,", Commonwealth 1, no. 1 (1896): 7-9.

${ }^{110}$ Minutes of meeting held on 5 Dec 1894, Rainbow Circle, Coll Misc. 0575 2/2, LSE Archives. The Rainbow Circle had existed in a previous incarnation, but was reconstituted by Hobson, Wallas, MacDonald and others in 1894. 
It was shortly after this that Hobson began work on his biographical study of John Ruskin, which provided a further setting in which his views on machinery would develop. Among Hobson's intentions in that work was to sketch a version of political economy that would be committed to social reform, a combination made flesh in the figure of the Victorian sage. Hobson's aim was to support a view of Ruskin as "first and above all else a Political Economist" (a view made perhaps more mischievous for having been expressed already by the maverick Patrick Geddes in his 1884 work, John Ruskin, Economist). But, although the book was entitled John Ruskin, Social Reformer, the focus of subsequent scholarship has fallen mainly on the economics rather than the reform. Hobson claimed that Ruskin had provided "no greater service" than in his protest against the dominance of machine-based manufacturing and so was "right in his preachment against the grave danger of mechanising life at the present time." ${ }^{\prime 11}$ In advocating quality over quantity, Hobson merely ventriloquized Ruskin's well-known, if heterodox, positions on questions of taste. On the nature of machine-work, however, Hobson departed from Ruskin entirely, forcefully rejecting the belief that work with machinery was necessarily degrading and so ought to be reserved for an especially low or "Helot" class of person. ${ }^{112}$ Such a negative view was as implausible to Hobson as the opposite argument - advanced by enthusiasts such as CookeTaylor and to an extent by Marshall - that machinery improved workers' characters. The evident problems caused by machines as well as the unconvincing solutions proposed by those few contemporaries to have addressed the question (including Ruskin) were unacceptable to Hobson, whose commitment to reform continued in subsequent works.

\footnotetext{
${ }^{111}$ Hobson, John Ruskin, viii; 224-25.

${ }^{112}$ Ruskin, Fors Clavigera, IV: 208; II: 413 [Letters LXXXII \& XLIV]; Hobson, John Ruskin, 219. Colin Matthew's astute suggestion that Hobson could at times find himself in positions more conservative than those adopted by Ruskin, therefore, requires qualification when their respective views on machinery and labor are considered, Matthew, "Hobson, Ruskin and Cobden," 16.
} 
In 1900 Hobson contributed to a volume edited by his collaborator Stanton Coit in which his position regarding machinery had hardened. In his essay "The Ethics of Industrialism: a Diagnosis," Hobson depicted industrial capitalism as a system in meltdown and argued that solutions had become a matter of urgency. ${ }^{113}$ This essay is rightly noted by Michael Freeden as an example of Hobson's call for a systematic approach to social problems, but the cause of the problems under discussion: that is, machinery, is not mentioned. ${ }^{114}$ Hobson diagnosed a series of profound "maladjustments" between social and economic conditions that could only be understood by examining their origins in the Industrial Revolution.

The chief material agency and instrument of change has been machinery. Machinery has become the autocrat of modern industry, not only determining what work shall be done, how it shall be done, and who shall do it, but fixing the conditions of life for the workers, making modern towns, and stamping the conditions of machinemade towns upon the character of the nation. ${ }^{115}$

In this essay, Hobson reprised his previous themes but with more surety and gusto, now claiming that "dehumanising influences emanate from the reign of machinery" and that machine work destroys all spontaneity and pleasure. The responses to the iniquities of the Industrial Revolution had been, according to Hobson, emotional and sentimental and so "demanded a purely charitable treatment of the social maladies of a diseased industrialism." In particular, claimed Hobson, the portrayal of downtrodden workers in industrial fiction tended to attribute their plight to a particular cause such as an evil or negligent boss. Such

\footnotetext{
113 J. A. Hobson, "The Ethics of Industrialism: A Diagnosis," in Ethical Democracy: Essays in Social Dynamics, ed. Stanton Coit (London, 1900).

${ }^{114}$ Freeden, "J. A. Hobson As a New Liberal Theorist," at 425.

${ }^{115}$ Hobson, "The Ethics of Industrialism," 82-83. Hobson had commented at greater length on the character of industrial towns in chapter nine of his biography of Ruskin.
} 
examples of individual suffering did not admit of generalization and so missed finding their true cause. In Hobson's view the prevalence of such responses conspired to prevent a proper "understanding of the momentous issues that were gathering in the world of industry." ${ }^{116} \mathrm{By}$ contrast, Hobson's economic study of machinery aimed to provide an analysis that was compelling, systematic, and ethical. Hobson produced a new synthesis that refined the perspectives of Ruskin and Morris in the language of political economy, thereby creating his worldly yet optimistic belief in the possibility of reforming the relation of human and machine.

\section{CONCLUSIONS}

It is often claimed that the second South African War of 1899-1902 marked a shift in Hobson's focus to the question of imperialism. There can be no doubt that events in South Africa shaped Hobson profoundly. However, they should not be seen as having prompted a major shift in his thought so much as providing a focus for his existing concerns. The military and financial events in South Africa, which provided the subject of Hobson's most celebrated writing, should be understood in the wider context of his economic philosophy, not least because at the height of the conflict Hobson found time to write his essay, "The Ethics of Industrialism," just discussed. The machinery question was thus inseparable from geopolitics and Hobson's 1900 essay contains some of his most strident claims, which must be seen as intersecting consistently with a wider set of ethical and economic concerns. Hobson's lectures and his writings for various ethical and political journals, his many contributions to the Rainbow Circle, and his essays published around the year 1900 have not received sustained scholarly attention. This article has focused mainly on Hobson's early writings on machinery from the mid-1890s; however, even a brief survey suggests that the argument that

${ }^{116}$ Ibid., 83. 
machinery was integral to his political thought could be extended. Indeed, Hobson continued to write substantial pieces about industry, and the roles played by science and machinery throughout the 1900s and into the 1910s. Further studies might attend to his 1906 essay "Science and Industry" - which placed the themes already outlined in more direct connection with his overproduction thesis - as well as his writings from 1913 onwards on scientific management. ${ }^{117}$ The piecemeal nature of British industrialization meant that the teachings of productivist gurus such as Fredrick Winslow Taylor had little impact until later than was the case in the U.S. and Germany. ${ }^{118}$ It was only from around 1910 that Taylorism received sustained attention in Britain, culminating in a high profile controversy prompted by the industrialist Edward Cadbury who, in 1913, evaluated critically the possibility of implementing scientific management in his Bournville factory. ${ }^{119}$ This intense debate in the pages of the Sociological Review was in fact pre-dated by a long and detailed critique of Fordism published by Hobson the year before. ${ }^{120}$ It has been one aim of this article to show that it should not be surprising to find this New Liberal critic of empire intervening at length in a debate on mechanization in 1913-14, since this was a phenomenon that he had already been charting historically and economically for twenty years. Hobson's contribution to this debate revealed him as a rare British breed: neither pro- nor anti-machine, he was a sensitive critic who had long been alert to the emancipatory potential of machinery. However, he was equally aware that its practical application over time had failed to deliver on these promises; contriving instead to degrade, exhaust and mechanize workers, whose power as citizenconsumers was diminished into the bargain.

\footnotetext{
117 J. A. Hobson, "Science and Industry," in Science in Public Affairs, ed. J. E. Hand (London, 1906). ${ }^{118}$ For a finer grained account cf. Kevin Whitston, "The Reception of Scientific Management by British Engineers, 1890-1914." The Business History Review 71, no. 2 (1997), 207-29.

${ }^{119}$ Edward Cadbury, "Some Principles of Industrial Organization: The Case for and Against Scientific Management," Sociological Review 7, no. 2 (1914): 99-117. Cadbury's article was followed, in the same issue, with a long discussion of the topic, which featured contributions from G.D.H. Cole, C.G. Renold, W. Hazell, W.H. Jackson, and also J.A. Hobson. The following issue featured replies from Cadbury alongside one from F.W. Taylor himself.

${ }^{120}$ J.A. Hobson, "Scientific Management", Sociological Review 4, no. 3 (1913): 197-212;
} 
In light of the overview of Hobson's work presented here, any attempt to distinguish discrete periods within his corpus must be made carefully. His writings on machine industry before 1898 should not be seen merely as preparatory exercises for the later and more canonical concerns of imperialism and Labour Party economic policy, but were a consistent preoccupation which formed the core of his ethics. A critique of political economy that was both ethical and systematic led Hobson to attempt a deep analysis of socio-economic trends, in which machinery was repeatedly cast as a central agent of change, and whose effects demanded urgent attention. The economic context of the 1890s led Hobson to revert to an earlier model of inquiry in order to re-pose the machinery question—often considered to have been settled by the $1850 \mathrm{~s}$ - in the accessible and all-encompassing terms that had been used by the early Victorians, but this later re-posing of the debate did not generate substantial interest among his contemporaries. Despite the ever-increasing presence of machinery in the economy, the attention of economists had moved elsewhere. Maxine Berg points to the ongoing interest of certain thinkers such as Friedrich Engels and J.S. Mill in the machinery question after 1848; but overall, machinery is most notable for its absence from politicaleconomic debate in the latter half of the century. ${ }^{121}$ This invisibility may explain the curiosity that even scholars of Hobson have largely failed to register his interest in a question whose disregard exemplifies the more general absence of machinery from political discourse. Hobson's concerns with taste and consumption, with the relation of the individual to society, with the nature of work, money, and empire can be seen as a constellation of issues that necessarily revolved around the question of the machine.

The example of Hobson raises a broader set of questions about the writing of machinery into British history at which this article can only gesture an answer. By considering the type and style of thinker to have engaged with the question of machinery

${ }^{121}$ Berg, Machinery Question, Epilogue. 
(i.e., with the political questions arising from its deployment) it may be possible to sketch the sort of engagement - both in disciplinary and intellectual terms - needed to produce a meaningful analysis of technology, of which Hobson's etho-economics is an example. The challenge of charting, analyzing, and then debating the nature of the ongoing relation of human and machine is a task that falls, as it has fallen, to social, political and economic thinkers as well as to historians, and so the boundaries of these first- and second-order investigations are not impermeable. Economists have used historical data just as historians have employed the economic and the political. However it appears that historians of Britain have not been as effective as those, for example, of modern France in interrogating the role of machinery in its fullest political significance. ${ }^{122}$ This article has suggested that attempts to incorporate the question of technology into histories of Britain have not been equal to the impact technology is commonly held to have had on Britain's politics and economy. The range of topics which historians of British thought consider to be political might therefore be profitably enlarged to include machines and industry; just as historians of technology might broaden the range of figures under their consideration to those hybrid thinkers such as Hobson who- as this article has shown- sought to consider the effects of machinery as a whole.

\footnotetext{
${ }^{122}$ See for example the work of François Jarrige, e.g., most recently, Technocritiques: Du Refus Des Machines À La Contestation Des Technosciences (Paris, 2014).
} 